\title{
FRUIT YIELD AND NUTRITIONAL CHARACTERISTICS OF SWEET PEPPER GROWN UNDER SALT STRESS IN HYDROPONIC SYSTEM ${ }^{1}$
}

\author{
NADIELAN DA SILVA LIMA², ÊNIO FARIAS DE FRANÇA E SILVA², DIMAS MENEZES ${ }^{3}$, \\ TEREZINHA RANGEL CAMARA ${ }^{3}$, LILIA GOMES WILLADINO ${ }^{2 *}$
}

\begin{abstract}
Irrigation with brackish water is common in the semiarid region of the Brazilian Northeast, potentiating the process of salinization of the soil in these areas. The hydroponic system stands out as an important strategy for crop management in semiarid regions, since crops show greater tolerance to the salt stress under hydroponic conditions, which minimize the effects of soil salinization. Thus, the objective of this work was to evaluate the effects of salt stress on the growth, fruit yield and mineral nutrition of sweet pepper in hydroponic system, using brackish water and coconut fiber substrate. The experiment was conducted in Recife, State of Pernambuco, Brazil $\left(8^{\circ} 3^{\prime} 15^{\prime \prime} \mathrm{S}, 34^{\circ} 52^{\prime} 53^{\prime \prime} \mathrm{W}\right)$. A randomized block experimental design in a $5 \times 2$ factorial arrangement with five replications was used, consisting of five water salinity levels of the nutrient solution $\left(2.0 ; 3.5 ; 4.5 ; 5.5\right.$ and $\left.6.5 \mathrm{dS} \mathrm{m}^{-1}\right)$ and two sweet pepper cultivars (Bruno and Rubia). The increasing salinity level of the nutrient solution decreased the fruit yield of the cultivars evaluated, reduced the potassium, phosphorus and sulfur, and increased the sodium and chlorine contents in the leaf tissues. The $\mathrm{Ca}$ contents of the cultivar Bruno decreased with increasing salinity, and increased in the cultivar Rubia. The cultivar Rubia stood out with the highest fruit yield and ionic selectivity, accumulating high amounts of potassium and calcium and maintaining low $\mathrm{Na}$ and $\mathrm{Cl}$ contents. The fruit yield of the cultivar Rubia ( $\left.39.9 \mathrm{t} \mathrm{ha-}^{-1}\right)$ grown under solution with electrical conductivity of up to $3.5 \mathrm{dS} \mathrm{m}^{-1}$, denotes the potential viability of growing this cultivar under hydroponic conditions.
\end{abstract}

Keywords: Capsicum annuum L.. Tolerance to salinity. Mineral nutrition. Ionic selectivity. Sodium. Chloride.

\section{RENDIMENTO E CARACTERÍSTICAS NUTRICIONAIS DO PIMENTÃO CULTIVADO SOB ESTRESSE SALINO EM SISTEMA HIDROPONICO}

\begin{abstract}
RESUMO - A irrigação com águas salobra, frequente na região semiárida do nordeste brasileiro, potencializa o processo de salinização do solo nessas áreas. O cultivo hidropônico destaca-se como uma importante estratégia de convivência com o semiárido, uma vez que as culturas apresentam maior tolerância ao estresse salino nestas condições de cultivo, as quais minimizam os efeitos da salinização dos solos. O objetivo deste trabalho foi avaliar os efeitos da salinidade sobre o crescimento, produção e nutrição mineral de pimentão em cultivo hidropônico utilizando água salina em substrato de fibra de coco. $\mathrm{O}$ experimento foi conduzido em Recife, Pernambuco, Brasil $\left(8^{\circ} 3^{\prime} 15^{\prime \prime} \mathrm{S}, 34^{\circ} 52^{\prime} 53^{\prime \prime} \mathrm{W}\right)$. Foi utilizado o delineamento experimental em blocos casualizados com fatorial $5 \times 2$, com cinco repetições, consistindo em cinco níveis de salinidade da solução nutritiva $\left(2,0 ; 3,5 ; 4,5 ; 5,5\right.$ e $\left.6,5 \mathrm{dS} \mathrm{m}^{-1}\right)$ e duas cultivares de pimentão (Bruno e Rúbia). O incremento dos níveis de salinidade da solução nutritiva diminuiu a produção de frutos das cultivares avaliadas, reduziu os teores de potássio, fósforo e enxofre e aumentou os teores de sódio e cloro no tecido foliar. O teor de $\mathrm{Ca}$ da cv. Bruno decresceu em função do aumento da salinidade, e a apresentou aumento na cv. Rúbia. A cv. Rúbia destacou-se pela maior produtividade e maior eficiência na seletividade iônica, sendo capaz de acumular mais potássio e cálcio, e manter menores teores de $\mathrm{Na}$ e $\mathrm{Cl}$. A produtividade da cv. Rúbia $\left(39,9 \mathrm{t} \mathrm{ha}^{-1}\right)$ quando cultivada em solução com condutividade elétrica de até $3,5 \mathrm{dS} \mathrm{m}^{-1}$, indica a viabilidade potencial de seu cultivo em condições hidropônicas.
\end{abstract}

Palavras-chave: Capsicum annuum. Tolerância à salinidade. Nutrição mineral. Seletividade iônica. Sódio. Cloreto.

\footnotetext{
${ }^{*}$ Corresponding author

${ }^{1}$ Received for publication in $09 / 14 / 2016$; accepted in $05 / 03 / 2017$.

Paper extracted from the doctoral thesis of the first author.

${ }^{2}$ Department of Agricultural Engineering, Universidade Federal Rural de Pernambuco, Recife, PE, Brazil; nadielanlima@hotmail.com, enio.fsilva@ufrpe.br,willadino.lilia@gmail.com.

${ }^{3}$ Department of Agronomy, Universidade Federal Rural de Pernambuco, Recife, PE, Brazil; dimasmenezes@superig.com.br, teca.camara@gmail.com.
} 


\section{INTRODUCTION}

The Brazilian semiarid region has low irregular precipitation and high evapotranspiration. Water from underground reservoirs that could be used for agriculture often have high levels of dissolved salts, which can cause soil salinization and affect the productive capacity of crops.

Sweet pepper (Capsicum annuum L.) crops in the Brazilian semiarid region are carried out by small farmers and in areas where most of water sources have excess salts (COSME et al., 2011). The maximum soil salinity for growing sweet pepper without fruit yield losses is $1.5 \mathrm{dS} \mathrm{m}^{-1}$; above this limit the fruit yield decreases $14 \%$ per salinity unit $\left(\mathrm{dS} \mathrm{m}^{-1}\right.$ ) increased (VILLAS BÔAS; ZANINI; DUENHAS, 2002). According to Mengel et al. (2001), crops with decreased production under electrical conductivity of the saturated soil extract lower than $2.0 \mathrm{dS} \mathrm{m}^{-1}$, such as sweet pepper, are considered sensitive to salinity.

The salinity of the soil solution surrounding roots hinders the water and nutrients absorption, causing nutritional imbalance, decreasing the availability of essential ions due to antagonistic effects of $\mathrm{Na}^{+}$with $\mathrm{K}^{+}, \mathrm{Ca}^{2+}, \mathrm{Mg}^{2+}$, and $\mathrm{Cl}^{-}$with $\mathrm{NO}_{3}{ }^{-}, \mathrm{SO}_{4}^{-}, \mathrm{PO}_{4}{ }^{3-}$ (PRISCO; GOMES FILHO, 2010; FREIRE et al., 2010; KAHLAOUI et al., 2011; HAJIAGHAEI-KAMRANI; HOSSEINNIYA, 2013), thus decreasing the fruit yield of most crops (MUNNS; TESTER, 2008; DUMAN, 2012).

Matric potential contributes strongly to decrease the total water potential, decreasing water absorption by plants grown in the soil. Hydroponic system contributes to minimize this effect, since the small or non-existent contribution of the matric potential, due to the saturation to which plants are subjected, remaining only the osmotic potential, which increase the total water potential, decreasing the negative effects of using brackish water (SOARES et al., 2007). Positive results of hydroponic system with brackish water have shown its potential for vegetable crops, such as lettuce, tomato, rocket and sweet pepper (SOARES et al., 2007; SOARES et al., 2010; SILVA et al., 2012; NUNES et al., 2013; SANTOS et al., 2016). Therefore, the hydroponic system is an alternative for crops using brackish waters (SOARES et al., 2007).

In light of the above, this study aimed to evaluate to evaluate the effects of salt stress on the growth, fruit yield and mineral nutrition of two sweet pepper cultivars (Rubia and Bruno) in hydroponic system, using brackish water and coconut fiber substrate.

\section{MATERIAL AND METHODS}

The experiment was conducted during 120 days after transplanting (DAT) in a greenhouse at the Federal Rural University of Pernambuco (UFRPE), Recife, State of Pernambuco, Brazil ( $8^{\circ} 01^{\prime} 05^{\prime \prime} \mathrm{S}, 34^{\circ} 56^{\prime} 48^{\prime \prime} \mathrm{W}$; altitude $\left.6.5 \mathrm{~m}\right)$. A complete randomized block experimental design in a $5 \times 2$ factorial arrangement with five replications was used, consisting of five salinity levels of the nutrient solution $\left(2.0 ; 3.5 ; 4.5 ; 5.5\right.$ and $\left.6.5 \mathrm{dS} \mathrm{m}^{-1}\right)$ and two sweet pepper cultivars (Bruno and Rubia), totaling 10 treatments and 50 experimental plots. Each plot consisted of two sweet pepper plants, with one plant per pot.

Plants were transplanted to 8.0 liters polyethylene pots 35 days after planting. The substrate consisted of coconut powder $(2.0 \mathrm{~kg})$, which was air-dried and placed in the pots (SANTOS et al., 2016). Coconut powder is an inert substrate with insignificant effect on the matric potential (BARRETO; TESTEZLAF; SALVADOR, 2012).

The hybrid cultivars Bruno and Rubia have average cycle of 110 to 120 days. Commercial seedlings, with 35 days after planting and six leaves, were transplanted to the pots, with spacing of $0.5 \mathrm{~m}$ between pots and $1.0 \mathrm{~m}$ between rows (planting density of 20,000 plants per hectare). The plants were tutored to prevent lodging.

The drip irrigation system consisted of five 200 liters reservoirs with the five salinity levels of the nutrient solution, which was pumped to bypass lines consisted of polyethylene hoses $(16.0 \mathrm{~mm}$ diameter), from which originated microtubes (5.0 $\mathrm{mm}$ diameter) with pressure compensating drippers (flow rate of $4.0 \mathrm{~L} \mathrm{~h}^{-1}$ ), and each dripper directed to a replication of the treatment. The plants were irrigated once a day, according to the need of the crop for each development stage. The irrigation was ended when the pot capacity was reached and the solution begun to drain.

The salt solutions were prepared with water and $\mathrm{NaCl}$ considering the four electrical conductivity levels of the nutrient solution (ECsol) $(1.5,2.5,3.5$ and $\left.4.5 \mathrm{dS} \mathrm{m}^{-1}\right)$. The salts of the nutrient solution (FURLANI et al., 1999) were then added to the final ECsol of 3.5, 4.5, 5.5 and $6.5 \mathrm{dS} \mathrm{m}^{-1}$, and a treatment consisted of a solution of $2.0 \mathrm{dS} \mathrm{m}^{-1}$ was used as control. The salinity levels chosen were according to Nunes et al. (2013).

The pre-flowering nutrient solution consisted of $750 \mathrm{~g} \mathrm{~L}^{-1}$ of calcium nitrate, $450 \mathrm{~g} \mathrm{~L}^{-1}$ of potassium nitrate, $200 \mathrm{~g} \mathrm{~L}^{-1}$ of mono-ammonium phosphate (MAP), $400 \mathrm{~g} \mathrm{~L}^{-1}$ of magnesium sulfate, $25 \mathrm{~g} \mathrm{~L}^{-1}$ of iron chelate - EDDHA-Fe - and $25 \mathrm{~g} \mathrm{~L}^{-1}$ of a solid mix of micronutrient chelated by EDTA. The fruiting nutrient solution consisted of the pre-flowering solution plus $75 \mathrm{~mL} \mathrm{~L}^{-1}$ of boric acid solution $\left(25 \mathrm{~g} \mathrm{~L}^{-1}\right)$ and $150 \mathrm{~g} \mathrm{~L}^{-1}$ of mono-potassium phosphate (MKP). The $\mathrm{pH}$ of the solution was maintained between 5.0 and 6.0. 
The number of fruits per plant, average fruit weight $\left(\mathrm{g}\right.$ fruit $\left.^{-1}\right)$ and fruit yield $\left(\mathrm{t} \mathrm{ha} \mathrm{ha}^{-1}\right)$ were evaluated. Fruit yield was determined by multiplying the average fruit weight per plant $(\mathrm{kg})$ by the plant density (20,000 plants per ha) and the result was divided by 1000 , thus obtaining the productivity value, in tons per hectare $\left(\mathrm{t} \mathrm{ha}^{-1}\right)$. The fruits were weighed in an analytical precision scales $(0.01 \mathrm{~g})$. The fruits of five harvests during the experiment were quantified. The first harvest started at $63 \mathrm{DAT}$, when the fruits reached the marketing stage (green), and the last one at 120 DAT.

$\mathrm{P}, \mathrm{K}, \mathrm{Ca}, \mathrm{Mg}, \mathrm{S}, \mathrm{Cl}$ and $\mathrm{Na}$ contents in the leaf tissue of the plants were evaluated in dry, ground, and digested samples in a CEM microwave oven (ABREU et al., 1995). P was determined by colorimetry; sodium and potassium by flame photometry; calcium and magnesium by atomic absorption spectrometry; sulfur by turbidimetry of barium sulfate; and chloride through titration with silver nitrate (Mohr's method) (MALAVOLTA; VITTI; OLIVEIRA, 1997).

The means were subjected to analysis of variance. The quantitative factor (salinity level of the nutrient solution) was analyzed by regression, and the qualitative factor (sweet pepper cultivars) was analyzed by comparisons of means by the Tukey test at $5 \%$.

\section{RESULTS AND DISCUSSION}

The fruit yield of the sweet pepper cultivars evaluated (Bruno and Rubia) had a significant interaction with the electrical conductivity (salinity level) of the nutrient solution (ECsol). Independently, the factors cultivars and ECsol significantly affected all production variables (Table 1).

Table 1. Analysis of variance of number of fruits per plant, average fruit weight ( $\left.\mathrm{g} \mathrm{fruit}^{-1}\right)$ and fruit yield $\left(\mathrm{Mg} \mathrm{ha}^{-1}\right) \mathrm{of} \mathrm{the}$ sweet pepper cultivars Bruno and Rubia (C), as a function of electrical conductivity (salinity levels) of the nutrient solution (ECsol).

\begin{tabular}{ccccc}
\hline Source of & Degrees & \multicolumn{3}{c}{ Mean square } \\
variation & of freedom & Number of fruits per plant & Average fruit weight & Fruit Yield \\
\hline Block & 4 & $17.98^{\mathrm{ns}}$ & $265.85^{\mathrm{ns}}$ & $119.28^{*}$ \\
ECsol & 4 & $627.13^{* *}$ & $6381.02^{* *}$ & $4228.55^{* *}$ \\
C & 1 & $212.18^{* *}$ & $7177.86^{* *}$ & $1976.54^{* *}$ \\
ECsol x C & 4 & $16.63^{\mathrm{ns}}$ & $70.09^{\mathrm{ns}}$ & $136.59^{*}$ \\
Error & 36 & 10.52 & 109.87 & 35.54 \\
CV $(\%)$ & - & 20.45 & 17.25 & 25.92 \\
\hline & & & Mean Values & \\
\hline Bruno & - & $13.80 \mathrm{~b}$ & $48.80 \mathrm{~b}$ & $16.71 \mathrm{~b}$ \\
Rubia & - & $17.92 \mathrm{a}$ & $72.76 \mathrm{a}$ & $29.28 \mathrm{a}$ \\
\hline
\end{tabular}

$\mathrm{CV}=$ Coefficient of variation. Means followed by the same letter in the column do not differ at 0.05 of probability by the Tukey test. ${ }^{\text {ns }}=$ Not significant at 0.05 of probability by the $\mathrm{F}$ test. ${ }^{*}=$ significant at 0.05 of probability by the $\mathrm{F}$ test and $* *=$ significant at 0.01 of probability by the $\mathrm{F}$ test.

The number of fruits decreased linearly with the increase in the salinity, with significant effect on both cultivars (Figure 1A). Losses due to salinity reached $12.4 \%$ per unit increase in the nutrient solution salinity $\left(\mathrm{dS} \mathrm{m}^{-1}\right)$. The number of fruits of the cultivar Rubia, 30 to 11 , were higher than those of the cultivar Bruno, 26.6 to 7.4 fruits plant ${ }^{-1}$, when applying the highest ECsol $\left(6.5 \mathrm{dS} \mathrm{m}^{-1}\right)$. A similar work with the hybrid Eliza reported a decrease in number of fruits from 19 to 13, with plants grown with ECsol from 1.5 to $6.0 \mathrm{dS} \mathrm{m} \mathrm{m}^{-1}$, in water containing calcium nitrate and potassium chloride (LEONARDO et al., 2008). The cultivar Rubia showed higher fruit weight, varied within a range of 109 to $46 \mathrm{~g}_{\text {fruit }}{ }^{-1}$. The linear decrease of the fruit weight with increasing ECsol resulted in losses of $14.8 \%$ per unit increase in the nutrient solution salinity $\left(\mathrm{dS} \mathrm{m}^{-1}\right)$ (Figure $\left.1 \mathrm{~B}\right)$. The fruit weight of the cultivars decreased 57.7\% (Rubia) and 68\% (Bruno) with the highest ECsol compared with the control $\left(2.0 \mathrm{dS} \mathrm{m}^{-1}\right)$. These results were directly related to fruit yield, which decreased with increasing ECsol (Figure 1C). The fruit yield losses of the cultivars reached $85 \%$ (Rubia) and 91\% (Bruno) under the highest ECsol. These losses were expected, since a good development and production of sweet pepper crop requires a nutrient solution with ECsol of 2.0 to $3.0 \mathrm{dS} \mathrm{m}^{-1}$ (FURLANI et al., 1999).

Hydroponic system with brackish water in nutrient flow technique (NFT) is a closed system, in which the solution continuously circulates in the system. The advantages of this system for crops with use of brackish water are the absence of direct contact with the environment, which avoid soil salinization, and the more efficient use of water and fertilizers. Thus, NFT hydroponic is a potential 
alternative for crop systems in semiarid regions. The fruit yield of the cultivar Rubia in the hydroponic system with brackish water ECsol of up to $3.5 \mathrm{dS} \mathrm{m} \mathrm{m}^{-1}$ was $39.9 \mathrm{t} \mathrm{ha}^{-1}$, and the sweet pepper fruit yield grown in the field without salt stress is 25 to $40 \mathrm{tha}^{-1}$
(EMBRAPA, 2016), denotes the potential viability of using brackish water with ECsol of up to $3.5 \mathrm{dS} \mathrm{m}^{-1}$ to grow this cultivar in hydroponic system.

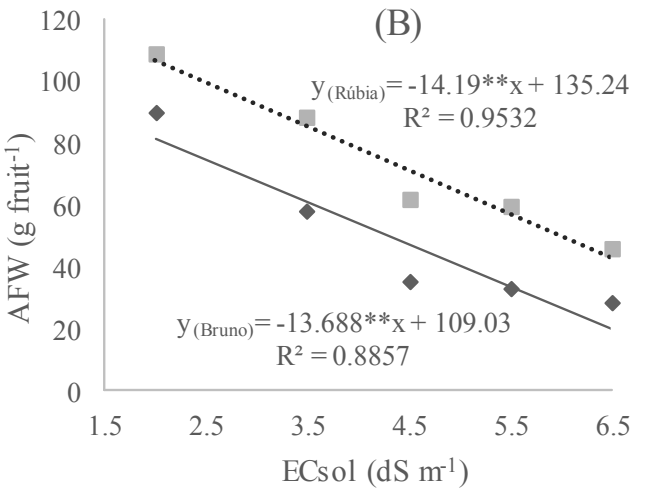

(C)

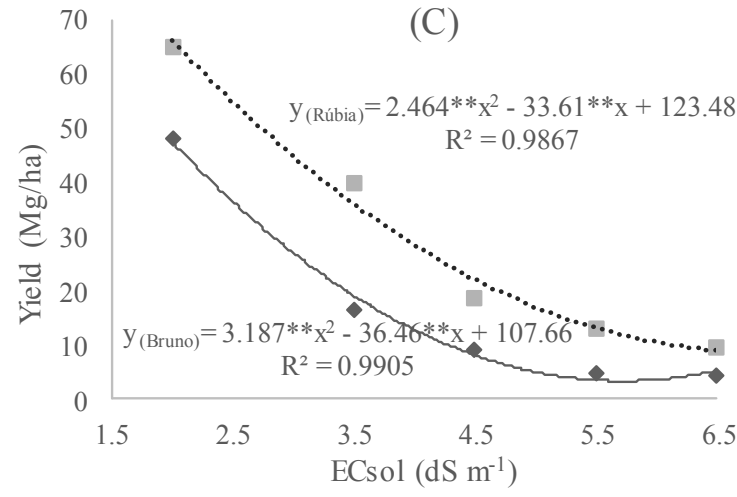

Figure 1. Regression analysis of the number of fruits per plant (NF) (A), average fruit weight (AFW) (B) and fruit yield (C) of the sweet pepper cultivars Bruno and Rubia as a function of the electrical conductivity of the nutrient solution (ECsol).

According to the analysis of variance of the mineral nutrient contents in the sweet pepper leaves, the interaction of the ECsol with the cultivars affected their calcium, sodium and chloride contents (Table 2). It was observed the isolated effect of
ECsol levels on the contents of phosphorus, potassium, sulfur, sodium and chloride. The cultivars factor had a significant effect for all evaluated nutrients, except for magnesium and sulfur.

Table 2. Analysis of variance of phosphorus $(\mathrm{P})$, potassium $(\mathrm{K})$, calcium $(\mathrm{Ca})$, magnesium $(\mathrm{Mg})$, sulfur $(\mathrm{S})$, sodium $(\mathrm{Na})$ and chlorine $(\mathrm{Cl})$ contents $\left(\mathrm{g} \mathrm{kg}^{-1}\right)$ in the sweet pepper cultivars Bruno and Rubia $(\mathrm{C})$, as a function of electrical conductivity of the nutrient solution (ECsol).

\begin{tabular}{|c|c|c|c|c|c|c|c|c|}
\hline \multirow{2}{*}{$\begin{array}{l}\text { Source of } \\
\text { variation }\end{array}$} & \multirow{2}{*}{ DF } & \multicolumn{7}{|c|}{ Mean square } \\
\hline & & $\mathrm{P}$ & $\mathrm{K}$ & $\mathrm{Ca}$ & $\mathrm{Mg}$ & $\mathrm{S}$ & $\mathrm{Na}$ & $\mathrm{Cl}$ \\
\hline Block & 4 & $0.2 * *$ & $6.24^{\mathrm{ns}}$ & $51.3 * *$ & $0.32^{\mathrm{ns}}$ & $0.07 * *$ & $0.90^{\mathrm{ns}}$ & $7.41^{\mathrm{ns}}$ \\
\hline ECsol & 4 & $2.006 * *$ & $147.28 * *$ & $8.50^{\mathrm{ns}}$ & $0.50^{\mathrm{ns}}$ & $0.03 *$ & $149.90 * *$ & $608.03 * *$ \\
\hline $\mathrm{C}$ & 1 & $0.38 * *$ & $222.61 * *$ & $48.15 * *$ & $0.15^{\mathrm{ns}}$ & $0.008^{\mathrm{ns}}$ & $221.37 * *$ & 892.56 ** \\
\hline ECsol x C & 4 & $0.03^{\mathrm{ns}}$ & $8.19^{\mathrm{ns}}$ & $14.34 *$ & $0.06^{\mathrm{ns}}$ & $0.005^{\mathrm{ns}}$ & $11.74 * *$ & $80.5 * *$ \\
\hline Error & 36 & 0.05 & 12.88 & 3.95 & 0.29 & 0.008 & 2.70 & 9.71 \\
\hline \multirow[t]{2}{*}{ CV $(\%)$} & - & 11.09 & 21.78 & 13.82 & 7.79 & 8.69 & 21.85 & 21.11 \\
\hline & & \multicolumn{7}{|c|}{ Mean values } \\
\hline Bruno & - & $1.93 \mathrm{~b}$ & $14.37 \mathrm{~b}$ & $13.41 \mathrm{~b}$ & $6.87 \mathrm{a}$ & $1.07 \mathrm{a}$ & $9.63 \mathrm{a}$ & $18.99 \mathrm{a}$ \\
\hline Rubia & - & $2.11 \mathrm{a}$ & $18.59 \mathrm{a}$ & $15.38 \mathrm{a}$ & $6.98 \mathrm{a}$ & $1.10 \mathrm{a}$ & $5.42 \mathrm{~b}$ & $10.54 \mathrm{~b}$ \\
\hline
\end{tabular}

$\mathrm{CV}=$ Coefficient of variation, $\mathrm{DF}=$ Degrees of freedom. Means followed by the same letter in the column do not differ at 0.05 of probability by the Tukey test. ${ }^{\mathrm{ns}}=$ Not significant at 0.05 of probability by the $\mathrm{F}$ test. $*=$ significant at 0.05 of probability by the $\mathrm{F}$ test and $* *=$ significant at 0.01 of probability by the $\mathrm{F}$ test. 
The $\mathrm{Na}$ and $\mathrm{Cl}$ contents in the leaf dry matter of the cultivar Rubia were lower in all treatments receiving $\mathrm{NaCl}$ in the nutrient solution (Table 3). Shoot accumulation of $\mathrm{Na}$ and $\mathrm{Cl}$ depends on the genotypic capacity to exclude these ions by transpiration (WILLADINO; CAMARA, 2010). The cultivar Bruno, on the other hand, had the lowest $\mathrm{Ca}$ contents, except in the plants grown with the lowest level of $\mathrm{NaCl}$ in the nutrient solution. Calcium deficiency often causes spots (black area) on the surface of the sweet pepper fruit, which is known as blossom end rot (TAYLOR; LOSCASCIO, 2004). The cultivar Bruno showed this symptom from $4.5 \mathrm{dS} \mathrm{m}^{-1}$. The addition of $\mathrm{NaCl}$ to the nutrient solution resulted in Ca contents lower than $13 \mathrm{~g} \mathrm{~kg}^{-1}$ in the cultivar Bruno, which is lower than the adequate $\mathrm{Ca}$ content for sweet pepper at fruit production stage (MILLS; JONES JUNIOR, 1996).

Table 3. Average calcium $(\mathrm{Ca})$, sodium $(\mathrm{Na})$ and chlorine $(\mathrm{Cl})$ contents $\left(\mathrm{g} \mathrm{kg}^{-1}\right)$ in the sweet pepper cultivars Bruno and Rubia as a function of salinity levels of the nutrient solution $\left(\mathrm{dS} \mathrm{m}^{-1}\right)$.

\begin{tabular}{|c|c|c|c|c|c|c|}
\hline \multirow{2}{*}{ Salinity levels } & \multicolumn{2}{|c|}{$\mathrm{Ca}$} & \multicolumn{2}{|c|}{$\mathrm{Na}$} & \multicolumn{2}{|c|}{$\mathrm{Cl}$} \\
\hline & Bruno & Rubia & Bruno & Rubia & Bruno & Rubia \\
\hline 2.0 & $16.05 \mathrm{~A}$ & $14.03 \mathrm{~A}$ & $2.10 \mathrm{~A}$ & $1.27 \mathrm{~A}$ & $2.32 \mathrm{~A}$ & $1.91 \mathrm{~A}$ \\
\hline 4.5 & $13.18 \mathrm{~B}$ & $16.46 \mathrm{~A}$ & $9.81 \mathrm{~A}$ & $6.55 \mathrm{~B}$ & $22.79 \mathrm{~A}$ & $11.25 \mathrm{~B}$ \\
\hline 5.5 & $11.66 \mathrm{~B}$ & $15.38 \mathrm{~A}$ & $11.89 \mathrm{~A}$ & $6.27 \mathrm{~B}$ & $26.52 \mathrm{~A}$ & $13.55 \mathrm{~B}$ \\
\hline 6.5 & $12.61 \mathrm{~B}$ & $16.99 \mathrm{~A}$ & $15.23 \mathrm{~A}$ & $9.19 \mathrm{~B}$ & $28.03 \mathrm{~A}$ & 15.24 B \\
\hline
\end{tabular}

*Means followed by the same letter in the column do not differ from each other at 0.05 of probability by the Tukey test.

The contents of $\mathrm{P}, \mathrm{K}$ and $\mathrm{S}$ in the leaves of both cultivars showed linear decreases with increasing salinity (Figure 2). The $\mathrm{P}$ content reduced $7.3 \%$ per unit increase in the nutrient solution salinity $\left(\mathrm{dS} \mathrm{m}^{-1}\right)$ (Figure $\left.2 \mathrm{~A}\right)$. The average levels of $\mathrm{P}$ in the cultivar Bruno did not exceed $1.81 \mathrm{~g} \mathrm{~kg}^{-1}$ under saline conditions, which is below the adequate $\mathrm{P}$ content, $2.0 \mathrm{~g} \mathrm{~kg}^{-1}$, for sweet pepper (TRANI; RAIJ, 1997). The cultivar Rubia, on the other hand, had $\mathrm{P}$ contents lower than $2.0 \mathrm{~g} \mathrm{~kg}^{-1}$ only under the highest ECsol. Decreased $\mathrm{P}$ contents due to increasing salinity were caused probably by the high levels of the $\mathrm{Cl}$ ion, which can have antagonistic interactions with phosphorus (FREIRE et al., 2010; KAHLAOUI et al., 2011; HAJIAGHAEI-KAMRANI; HOSSEINNIYA, 2013), however, there is no clear evidence of the interaction between salinity and changes in phosphorus absorption (DUMAN, 2012).

The contents of $\mathrm{K}$ in the leaf tissues decreased with increasing ECsol (Figure 2B), confirming the effect of salt stress by the high concentration of $\mathrm{Na}$ (DUMAN, 2012).

The average contents of $\mathrm{K}$ varied from from 21.9 to $10.2 \mathrm{~g} \mathrm{~kg}^{-1}$ in the cultivar Bruno and from 23.1 to $15.7 \mathrm{~g} \mathrm{~kg}^{-1}$ in the cultivar Rubia. These $\mathrm{K}$ contents were below the appropriate range for sweet pepper (40 to $60 \mathrm{~g} \mathrm{~kg}^{-1}$ ) (TRANI; RAIJ, 1997). The $\mathrm{K}$ content reduced $8.0 \%$ per unit increase in the nutrient solution salinity $\left(\mathrm{dS} \mathrm{m}{ }^{-1}\right)$. A reduction in $\mathrm{K}$ content in the cytoplasm can occur due to depolarization of the plasma membrane in roots under salt stress; and the activation of channels induced by reactive oxygen species favors $\mathrm{K}$ efflux (FLOWERS; MUNNS; COLMER, 2014).

$\mathrm{Ca}$ content in the leaves of the cultivar Rubia increased $5.20 \%$ per $\mathrm{dS} \mathrm{m} \mathrm{m}^{-1}$. The contents of $\mathrm{Ca}$ ranged from 14.0 to $16.9 \mathrm{~kg}^{-1}$ (Figure 2C), with contents always higher than that of the cultivar Bruno, which had decreases in $\mathrm{Ca}$ contents with increasing ECsol, showing the efficiency of $\mathrm{Ca}$ absorption by the cultivar Rubia under salt stress. The Ca content of the cultivar Rubia were close to those of experiments with sweet peppers hybrids Eliza, 6.8 to $13.0 \mathrm{~g} \mathrm{~kg}^{-1}$ throughout the crop cycle (MARCUSSI, 2005), and Atlantis, 13.0 to $15 \mathrm{~g} \mathrm{~kg}^{-1}$ (OLIVEIRA et al., 2015).

Variations in $\mathrm{Mg}$ contents of the cultivars were not significant and not affected by ECsol. The average $\mathrm{Mg}$ contents in the cultivars were 6.8, Bruno, and $6.9 \mathrm{~g} \mathrm{~kg}^{-1}$, Rubia. Even under salt stress, $\mathrm{Mg}$ leaf contents were within the adequate range for sweet pepper crop (3.0 to $10.0 \mathrm{~g} \mathrm{~kg}^{-1}$ ) (TRANI; RAIJ, 1997). These average $\mathrm{Mg}$ contents were close to those found for the cultivars Eliza, $3.3 \mathrm{~g} \mathrm{~kg}^{-1}$, (MARCUSSI, 2005), Amanda, $6.0 \mathrm{~g} \mathrm{~kg}^{-1}$, and Rubia, $6.2 \mathrm{~g} \mathrm{~kg}^{-1}$, (SEDIYAMA et al., 2014) in absence of salt stress.

$\mathrm{S}$ contents decreased linearly with increasing ECsol (Figure 2D), showing contents of 1.04 to $1.22 \mathrm{~g} \mathrm{~kg}^{-1}$. The average content of $\mathrm{S}$ found in the cultivars Amanda and Rubia in the absence of salt stress was 2.97 (SEDIYAMA et al., 2014). 


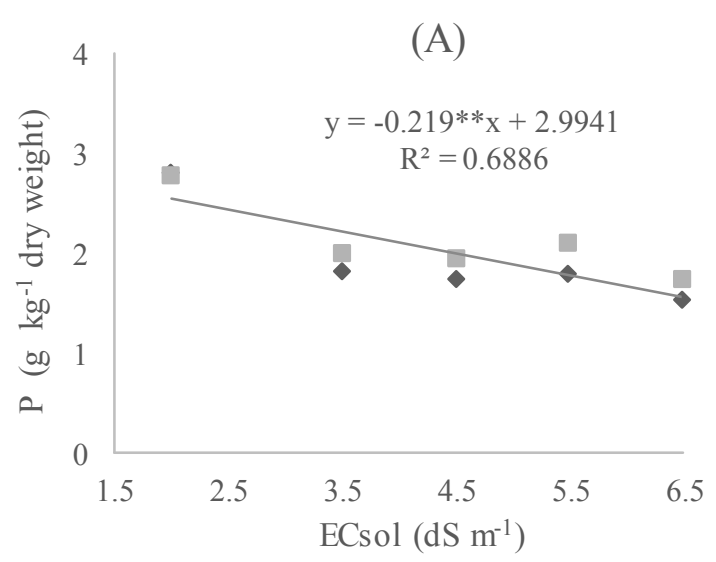

(C)
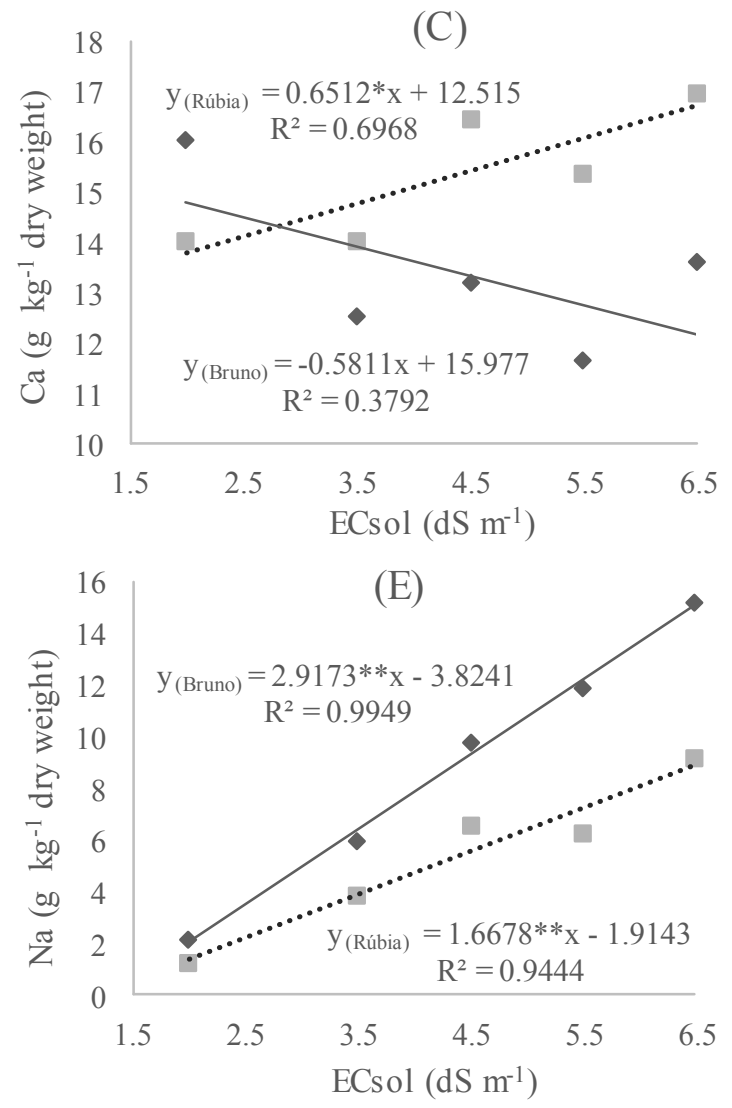

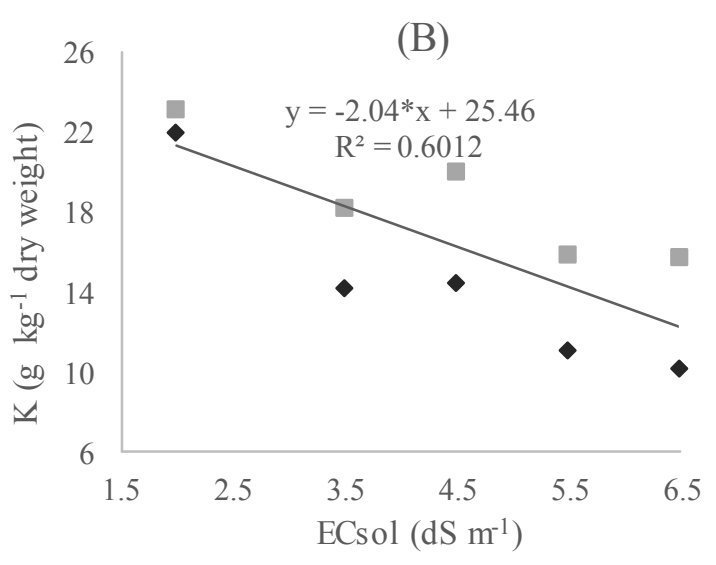

(D)
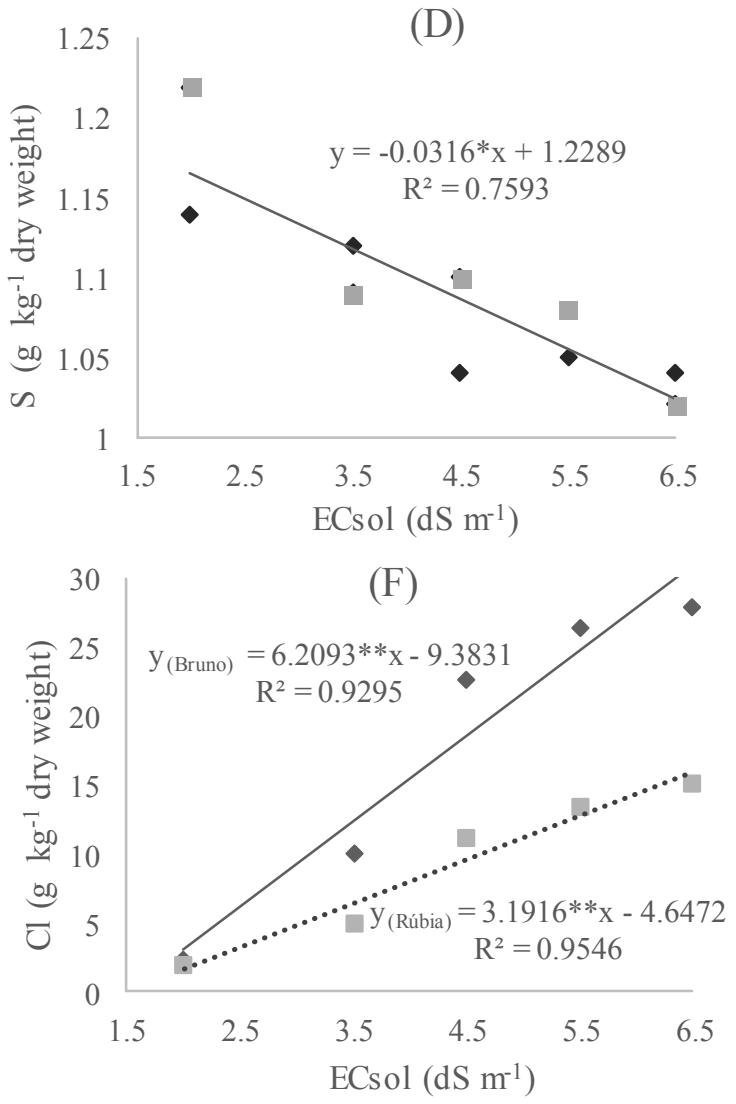

Figure 2. Analysis of regression of phosphorus (A), potassium (B), calcium (C), sulfur (D), sodium (E) and chloride (F) contents in the leaf tissue of the sweet pepper cultivars Bruno and Rubia as a function of electrical conductivity of the nutrient solution (ECsol).

The $\mathrm{Na}$ and $\mathrm{Cl}$ contents had linear increments with increasing ECsol in both cultivars. This increase was more pronounced in the cultivar Bruno, denoted by the angular coefficient of its regression curves (Figure 2E, 2F). The cultivar Bruno had increases of $87.3 \%(\mathrm{Na})$ and $68.6 \%(\mathrm{Cl})$, and Rubia had increases of $76.2 \%(\mathrm{Na})$ and $66.1 \%$ (Cl) per $\mathrm{dS} \mathrm{m}^{-1}$. The cultivar Rubia stood out by its ability of maintaining lower levels of these two ions when compared to the cultivar Bruno. Thus, the cultivar Rubia is more efficient in selective absorption of ions under salt stress than the cultivar Bruno, denoted by its greater capacity of absorption of $\mathrm{K}$ and $\mathrm{Ca}$ and limitation of absorption of $\mathrm{Na}$ and $\mathrm{Cl}$. Avoiding high concentrations of $\mathrm{Cl}$ and $\mathrm{Na}$ is fundamental to reduce damages to the photosynthetic apparatus and avoid inhibition of a large number of enzymes (WILLADINO; CAMARA, 2010).

The interaction between cultivars and levels of ECsol significantly affected the $\mathrm{Na}: \mathrm{K}$ and $\mathrm{Na}: \mathrm{Ca}$ ratios in the leaf tissue (Table 4). 
Table 4. Analysis of variance of Na:K and Na:Ca ratios of the sweet pepper cultivars Bruno and Rubia (C) as a function of electrical conductivity of the nutrient solution (ECsol).

\begin{tabular}{lccc}
\hline \multirow{2}{*}{ Source of variation } & Degrees of freedom & \multicolumn{2}{c}{ Mean square } \\
\cline { 2 - 4 } & 4 & $0.02 \mathrm{~ns}$ & $\mathrm{Na}: \mathrm{Ca}$ \\
\hline Block & 4 & $1.36^{* *}$ & $0.11 \mathrm{~ns}$ \\
ECsol & 1 & $2.93^{* *}$ & $0.83^{* *}$ \\
C & 4 & $0.24^{* *}$ & $2.27^{* *}$ \\
ECsol x C & 36 & 0.02 & $0.14^{*}$ \\
Error & - & 27.84 & 0.04 \\
CV (\%) & & & 36.04 \\
\hline & - & $0.81 \mathrm{a}$ & $0.78 \mathrm{a}$ \\
\hline Bruno & - & $0.31 \mathrm{~b}$ & $0.35 \mathrm{~b}$ \\
Rubia & & &
\end{tabular}

$\mathrm{CV}=$ Coefficient of variation. Means followed by the same letter in the column do not differ at 0.05 of probability by the Tukey test. ${ }^{\mathrm{ns}}=$ Not significant at 0.05 of probability by the $\mathrm{F}$ test. ${ }^{*}=$ significant at 0.05 of probability by the $\mathrm{F}$ test and $* *=$ significant at 0.01 of probability by the $\mathrm{F}$ test.
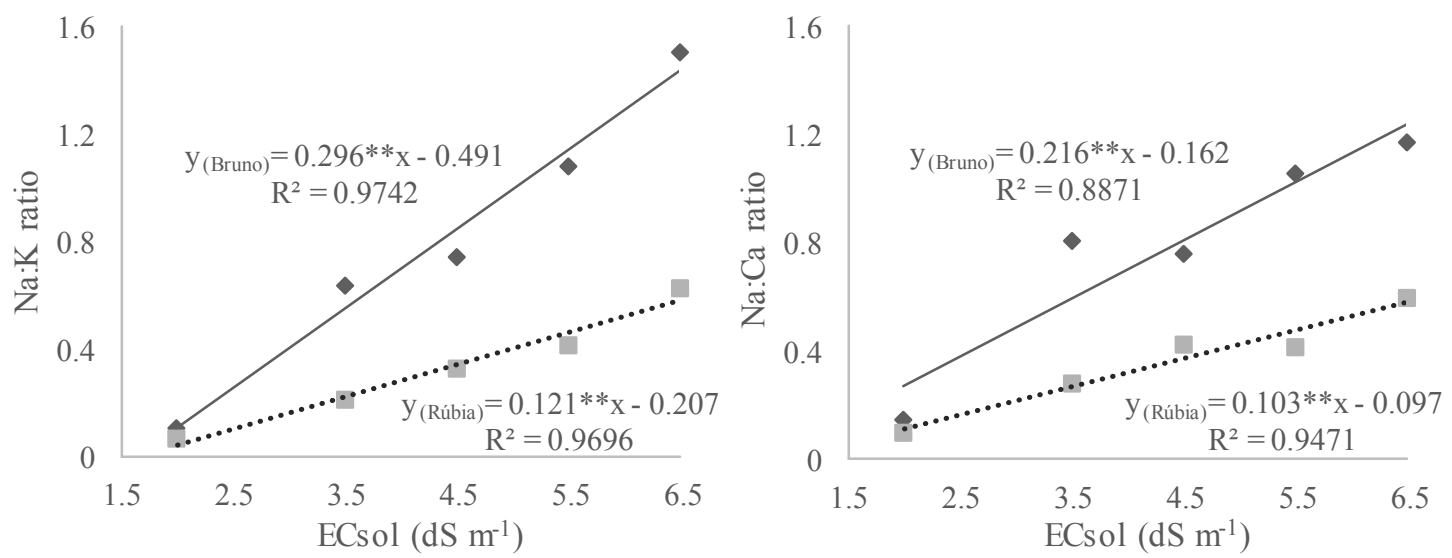

Figure 3. Regression analysis of $\mathrm{Na}: \mathrm{K}$ and $\mathrm{Na}: \mathrm{Ca}$ ratios in the leaf tissue of the sweet pepper cultivars Bruno and Rubia as a function of electrical conductivity of the nutrient solution (ECsol).

The leaf $\mathrm{Na}: \mathrm{K}$ and $\mathrm{Na}: \mathrm{Ca}$ ratios of both cultivars increased linearly with increasing ECsol (Figure 3). Under salinity conditions, with excess $\mathrm{Na}$ and $\mathrm{Cl}$, the high $\mathrm{Na}: \mathrm{K}$ and $\mathrm{Na}: \mathrm{Ca}$ ratio results in ionic toxicity $\left(\mathrm{Na}^{+}\right.$and $\left.\mathrm{Cl}^{-}\right)$and ionic imbalance (DUMAN, 2012). Salinity often inhibit absorption of potassium and calcium ions due to competition of sodium by absorption sites in the cell membrane, since $\mathrm{Na}$ is absorbed through $\mathrm{K}$-specific transporters and low affinity cation channels, or non-selective channels, the latter also transports $\mathrm{Na}, \mathrm{Ca}$ and $\mathrm{K}$ (MÄSER; GIERTH; SCHROEDER, 2002). The $\mathrm{Na}: \mathrm{K}$ ratio of the cultivar Bruno under salt stress was higher than 0.6 , and in the cultivar Rubia is equal to or lower than 0.6 , which is considered adequate for efficient maintenance of metabolism in non-halophytes (MUNNS; TESTER, 2008). Tolerance to salinity is correlated with maintenance of adequate potassium nutrition, and the $\mathrm{Na}: \mathrm{K}$ ratio can be used as a criterion to select sensitive and tolerant materials to salt stress (MUNNS; TESTER, 2008).

\section{CONCLUSIONS}

Increasing the salinity levels of the nutrient solution results in nutritional imbalance for the sweet pepper cultivars Rubia e Bruno, due to the decrease of potassium, phosphorus and sulfur contents and increase of $\mathrm{Na}$ and $\mathrm{Cl}$ contents in their leaves.

The cultivar Rubia shows higher fruit yield and is more effective in ionic selectivity, accumulating more potassium, calcium and phosphorus and maintaining lower contents of sodium and chloride in the leaf tissue than the cultivar Bruno.

The productivity of cv. Rúbia grown in the hydroponic system is potentially viable, without yield losses, using brackish water at electrical conductivities of the nutrient solution of up to $3.5 \mathrm{dS} \mathrm{m}^{-1}$.

\section{REFERENCES}

ABREU, C. A. et al. Comparação de métodos de análise para avaliar a disponibilidade de metais em 
solos. Revista Brasileira de Ciência do Solo, Campinas, v. 19, n. 3, p. 463-468, 1995.

BARRETO, C. V. G.; TESTEZLAF, R.; SALVADOR, C. A. Dinâmica do potencial matricial em substratos de pinus e coco sob ação da capilaridade. Horticultura Brasileira, Brasília, v. 30, n. 1, p. 26-31, 2012.

COSME, C. R. et al. Produção de tomate hidropônico utilizando rejeito da dessalinização na solução nutritiva aplicados em diferentes épocas. Revista Brasileira de Engenharia Agrícola e Ambiental, Campina Grande, v. 15, n. 5, p. 499504, 2011.

DUMAN, F. Uptake of mineral elements during abiotic stress. In: HAMAD, P.; PRASAD, M. N. V. (Ed.). Abiotic stress response in plants. London: Springer, 2012. v. 1, cap. 15, p. 267-282.

EMPRESA BRASILEIRA DE PESQUISA AGROPECUÁRIA - EMBRAPA. Pimentão. Disponível em: <http://www.cnph.embrapa.br/ capsicum/cpimentao.htm. $>$. Acesso em: 24 ago. 2016.

FLOWERS, T. J.; MUNNS R.; COLMER T. D. Sodium chloride toxicity and the cellular basis of salt tolerance in halophytes. Annals of Botany, Oxford, v. 115, n. 3, p. 419-431, 2014.

FREIRE, A. L. O. et al. Crescimento, acúmulo de íons e produção de tomateiro irrigado com água salina. Semina: Ciências Agrárias, Londrina v. 31, Sup., p. 1133-1144, 2010.

FURLANI, P. R. et al. Cultivo hidropônico de plantas. 1. ed. Campinas: IAC, 1999. 52 p. (Boletim técnico, 180).

HAJIAGHAEI-KAMRANI, M.; HOSSEINNIYA, H. Effect of salinity on nutrient uptake in tomato (Lycopersicon esculentum Mill.) in hydroponic system. International Journal of Agronomy and Plant Production, Ancara, v. 4, n. 10, p. 2729-2733, 2013.

KAHLAOUI, B. et al. Effects of saline water on tomato under subsurface drip irrigation: nutritional and foliar aspects. Journal of Soil Science and Plant Nutrition, La Araucanía, v. 11, n. 1, p. 69-86, 2011.

LEONARDO, M. et al. Estado nutricional e componentes da produção de plantas de pimentão conduzidas em sistema de fertirrigação durante indução de estresse salino em cultivo protegido. Bragantia, Campinas, v. 67, n. 4, p. 883-889, 2008.
MALAVOLTA, E.; VITTI, G. C.; OLIVEIRA, S. A. Avaliação do estado nutricional das plantas: princípios e aplicações. 2. ed. Piracicaba, SP: POTAFOS, 1997. 319 p.

MARCUSSI, F. F. N. Uso da fertirrigação e teores de macronutrientes em planta de pimentão. Revista Engenharia Agrícola, Jaboticabal, v. 25, n. 3, p. 642- 650, 2005.

MÄSER, P.; GIERTH, M.; SCHROEDER, J. I. Molecular mechanisms of potassium and sodium uptake in plants. Plant and Soil, Netherlands, v. 247, n. 1, p. 43-54, 2002.

MENGEL, K. et al. Principles of plant nutrition. 5. ed. Dordrecht: The Kluwer Academic Publishers, 2001. 849 p

MILLS, H. A.; JONES JUNIOR, J. B. Plant analysis handbook II. 2. ed. Athens: Micro-Macro, 1996. $422 \mathrm{p}$

MUNNS, R.; TESTER, M. Mechanisms of salinity tolerance. Annual Review Plant Biology, Los Angeles, v. 59, n. 1, p. 651-681, 2008

NUNES, R. L. C. et al. Efeitos da salinidade da solução nutritiva na produção de pimentão cultivado em substrato de fibra de coco. Revista Caatinga, Mossoró, v. 26, n. 4, p. 48-53, 2013.

OLIVEIRA, F. A. et al. Nutrição mineral do pimentão submetido a diferentes manejos de Fertirrigação. Horticultura Brasileira, Brasília, v. 33 , n. 3, p. 216-223, 2015.

PRISCO, J. T.; GOMES FILHO, E. Fisiologia e bioquímica do estresse salino. In: GHEYI, H. R.; LACERDA, C. F.; DIAS, N. S. (Eds.). Manejo da salinidade na agricultura: estudos básicos e aplicados. Fortaleza: Instituto Nacional de Ciência e Tecnologia em Salinidade, 2010. cap. 10, p. 143-159.

SANTOS, A. N. et al. Yield of cherry tomatoes as a function of water salinity and irrigation frequency. Revista Brasileira de Engenharia Agrícola e Ambiental, Campina Grande, v. 20, n. 2, p. $107-$ 112,2016

SEDIYAMA, M. A. N. et al. Nutrição e produtividade de plantas de pimentão colorido, adubadas com biofertilizante de suíno. Revista Brasileira de Engenharia Agrícola e Ambiental, Campina Grande, v. 18, n. 6, p. 588-594, 2014.

SILVA, A. O. et al. Consumo hídrico da rúcula em cultivo hidropônico NFT utilizando rejeitos de dessalinizador em Ibimirim-PE. Irriga, Botucatu, v. 17, n. 1, p. 114-125, 2012. 
SOARES, T. M. et al. Produção de alface utilizando águas salinas em sistema hidropônico. Irriga, Botucatu, v. 12, n. 2, p. 235-248, 2007.

SOARES, T. M. et al. Combinação de águas doce e salobra para produção de alface hidropônica. Revista Brasileira de Engenharia Agrícola e Ambiental, Campina Grande, v. 14, n. 7, p. 705-714, 2010.

TAYLOR, D.; LOCASCIO, S. J: Blossom - End Rot: A Calcium Deficiency, Journal of Plant Nutrition, Philadelphia, v. 27, n. 1, p. 123-139. 2004.

TRANI, P. E.; RAIJ, B. van. Recomendações de adubação e calagem para o Estado de São Paulo. 1. ed. Campinas: IAC, 1997. 279 p. (Boletim técnico, 100).

VILLAS BÔAS, R. L.; ZANINI, J. R.; DUENHAS, L. H. Uso e manejo de fertilizantes em fertirrigação. In: ZANINI, J. R.; VILLAS BÔAS, R. L.; FEITOSA FILHO, J. C. (Eds.). Uso e manejo da fertirrigação e hidroponia. Jaboticabal: Fundação de Apoio a Pesquisa, Ensino e Extensão, 2002. v. 1, cap. 1, p. 1$65 \mathrm{p}$.

WILLADINO, L.; CAMARA, T. R. Tolerância das plantas à salinidade: aspectos fisiológicos e bioquímicos. Enciclopédia Biosfera, Goiânia, v .6, n. 11, p. 1-23, 2010. 